\title{
Entrepreneurship Development Strategy Based on Local Awareness in Making Community Welfare (A Study in Disperindagkop Central Aceh)
}

\author{
Lukmannul Haqim ${ }^{1}$, Ika Hartika \\ ${ }^{1,2}$ Intitut Agama Islam Negeri Takengon, Indonesia \\ luqmannulhaqim_iyehn@yahoo.com
}

\begin{abstract}
Abundant natural resources are not a guarantee for the welfare of the people in a country. Another most important aspect in achieving prosperity is the strength of its human resources. Entrepreneurship as a solution in improving the standard of human life needs to be considered as an alternative. One of the roles of government in forming an entrepreneurial society has been carried out by Disperindagkop. Coffee is one of the commodities in Central Aceh. By creating more value from coffee, it is hoped that the people of Central Aceh will be able to increase their income. In making decisions requires a variety of considerations and careful design. ANP is a qualitative method for a decision-making process with a general framework without making assumptions about the independence of elements at a higher level than those at lower levels and about the independence of elements at a level. By using ANP, we know in detail which things are the most priority or important of problems, strategies and solutions, because sometimes there are a lot of policies or policy making, there are many limitations related to resources, so we need to know and understand which ones should be the first key / main problem or main strategy. After testing with ANP, it is found that the most priority aspect in determining the entrepreneurship development strategy is based on local wisdom is the entrepreneur / community, followed by Disperindag and the last one is academics. Creating individuals who have an entrepreneurship spirit is not an easy job. It takes a variety of education and training related to entrepreneurs and has become part of the government's responsibility for the welfare of its people, and one way is to educate people to become strong entrepreneurs.
\end{abstract}

Keywords

development strategy,

entrepreneurship, local wisdom

\section{Introduction}

Humans living in the world are given duties and responsibilities as caliph. This is supported by the advantages of reason and mind compared to other creatures. It is human nature that every human being is born to have different skills and abilities. This difference is natural because every human being is different in terms of culture, ethnicity, customs, language, interests, physical conditions and so on. This difference is not something that causes disputes because basically in Islam these differences give birth to wisdom which is sometimes often not realized by humans. Various problems in a country are of course also due to differences. The difference in income levels is also influenced by the level of expertise or skills someone has. One of the economic problems in Indonesia is the unemployment rate which is getting higher from year to year. Difficulties in finding employment are not only experienced by people with low education but also many scholars 
Konfrontasi Journal: Culture, Economy and Social Changes, 7 (4) December 2020, 322-330

ISSN: 1410-881X (Print), 2716-2095 (Online)

Lukmannul Haqim, Ika Hartika: Entrepreneurship Development Strategy Based on Local Awareness in Making Community Welfare (A Study in Disperindagkop Central Aceh)

DOI: https://doi.org/10.33258/konfrontasi2.v7i4.130

http://www.konfrontasi.net/index.php/konfrontasi2

who become unemployed. The large number of people with college degrees and the desire to be able to fulfill their daily needs is a factor that triggers people to look for work.

In addition to this in the era of free trade, entrepreneurs take various ways to get the maximum profit, for example being dishonest in running their business without thinking about the dangers to consumers. One of the efforts to increase the economic potential of the people and build an independent society is the birth of as many new entrepreneurs as possible. A simple assumption, entrepreneurship is basically independence, especially economic independence and independence is empowerment in achieving the fulfillment of life's needs.

Entrepreneurship or often referred to as entrepreneurship has a goal so that everyone has an independent attitude in dealing with life's problems. Independent in the sense of not "not needing other people", but can train oneself to move forward in order to meet the needs of today and in the future. Sharing with others, at times generates more income. Entrepreneurshipit is believed to be an opportunity to build the progress of a nation as well as a key to economic growth and the creation of new jobs.

Economic independence can be achieved through the fulfillment of life necessities accompanied by the ability to fulfill these needs. Here the government is required to be able to explore, elaborate and optimize its local potential. Most companies that are growing and which are innovative show an entrepreneurial spirit. According to J. Winardi, corporations are trying to encourage their managers to become entrepreneurs, universities are developing entrepreneurship programs, and individual entrepreneurs cause dramatic changes in society. Unfortunately, the number of entrepreneurs in Indonesia is still small and the quality cannot be said to be great to sustain the economy. So that this entrepreneurial problem becomes an urgent issue for the success of economic development in Indonesia. It is undeniable that entrepreneurship can help provide so many job opportunities, various consumer needs, services, and foster the welfare and level of competition of a country. Along with the development of globalization, entrepreneurship is also increasingly becoming an important concern in facing the challenges of globalization, namely global economic competition in terms of creativity and innovation. Through an entrepreneurial spirit, new business units need to be built in order to accommodate excess labor. Entrepreneurs have a big share in economic development through the creation of innovation, employment and welfare. The business world that is built by entrepreneurs will encourage the development of productive sectors. The more a country has entrepreneurs, the higher the country's economic growth will be.

Efforts at the capital system by avoiding the usury system are directed at the basis of local wisdom and sharia to realize the economic welfare of the community. The people of Central Aceh who are synonymous with making efforts to create economic prosperity give priority to entrepreneurship based on local wisdom and sharia. Thus the relationship between adat and Islam affects all cultural values and social norms of the Gayo community which refer to Islamic teachings. This can be used as a reference for revitalizing the basis of local wisdom in the field of entrepreneurship. All daily activities of the community must be in accordance with the demands of sharia, with the aim of being able to prosper the community through developing available natural potentials. One example is coffee, where Central Aceh is famous for the best coffee income. Currently, there are many people who are starting to get involved in the coffee processing business, this is indicated by the start of the number of coffee shop businesses in Central Aceh. In addition to the coffee shop, there are also many people who sell coffee in modified cars in the form of unit cafes.

The increasing number of modern coffee traders from an economic point of view can improve the economy and people's welfare. In the course of this activity must be fully 
supported by the government. The Office of Trade, Small and Medium Enterprises Cooperatives of Central Aceh Regency as part of the government must have a strategy in increasing independent and prosperous MSMEs. In increasing the number of MSMEs, people with good spirits are neededentrepreneurship.Entrepreneurship development in the community in accordance with local wisdom is expected to increase the welfare level of the Gayo community in Central Aceh District.

\section{Review of Literatures}

Every business must need a strategy in order to achieve its goals as well as business in terms of trade. Strategy has a broad definition and contains a variety of definitions. Understanding the strategy according to several sources obtained, namely: in general, the definition of a strategy is a way to achieve goals. Strategy is a long-term plan to achieve goals. Strategy consists of important activities needed to achieve goals. ${ }^{1}$ Meanwhile, according to the Big Indonesian Dictionary (KBBI) a strategy is a careful plan regarding activities to achieve specific goals. ${ }^{2}$ The term strategy comes from Greek (Stratos $=$ military and Ag which means leader), which means generalship or something done by war generals in making plans to win the war. ${ }^{3}$

Marketing strategy is a plan that outlines the company's expectations of the impact of various marketing activities or programs on the demand for products or product lines in certain target markets". According to Andrews in Alma's book (2009: 199) that: "Marketing strategy is a pattern of decisions in company that determine and express goals, intentions or goals that produce the main policy and plan for the achievement of objectives and detail the range of business that will be pursued by the company (Dianto et al, 2020).

Promotion strategy is a concept that is close to communication science. In the promotion, there are various forms of communication learned in communication science such as advertising, publicity, communication from mouth to mouth, personal sales, and direct marketing. (Amin and Priansa, 2019).

According to Pontas in his book defining strategy is planning the long-term goals and objectives of an organization or company, determining the number and types of activities required, and the allotment of resources for its achievement. ${ }^{4}$ Michael Porter in his article entitled Competitive strategy in Harvard Business Review (1996), states that strategy is a set of different actions or activities to deliver unique values. Meanwhile, according to Chandler, strategy is the establishment of basic long-term goals and company goals, and the establishment of a series of actions, as well as the allocation of resources that are important to carry out the goals. According to the child strategy is a set of basic or critical choices regarding the goals and means of the business. According to Jhonson and Scholes, strategy is the direction and scope of an organization that is ideal for the longer term, which adapts its resources to a changing environment, and specifically with its market with customers and clients to determine stakeholder expectations. ${ }^{5}$

\footnotetext{
${ }^{1}$ Rachmat, Strategic Management, (Bandung: Cv Pustaka Setia, 2014), Hal. 2

${ }^{2}$ Ministry of National Education, Big Indonesian Dictionary: Language Center, (Jakarta: Gramedia Pustaka Utama, 2012), p. 1340

${ }^{3}$ Dita Amanah, Introduction to Management, (Bandung: Citapustaka Media Perintis, 2013), Hal. 116

${ }^{4}$ Pontas M. Pardede, Strategic Management and Corporate Policy, (Jakarta: Mitra Wacana Media, 2011), Page 28

${ }^{5}$ Teguh Santoso, Strategic Marketing to Increase Market Share and Competitiveness, (Jakarta: Oryza, 2011), page 14.
} 
The definition of development in the Big Indonesian Dictionary (KBBI) is the process, method, act of developing. ${ }^{6}$ Furthermore, the definition of development is the act of making more, perfect changes (thoughts, knowledge and so on). ${ }^{7}$ From the description above, development is a process used to develop and validate a product, development can be in the form of processes, products and designs.

Entrepreneurship comes from English which means businessman or entrepreneur. Entrepreneur means a person who starts (The Originator) a new business venture, which seeks to improve an organizational unit through a series of productive changes. The aim of Entrepreneurship is essentially driven for economic change, so the same factors that promote economic growth and development also influence the emergence of entrepreneurship. The characteristics of an entrepreneur are not something that comes by itself, but is produced from certain processes through the factors that deliver it. Here are some of these factors, namely:

1. Environmental factors, most successful entrepreneurs are people who were raised by parents who are also entrepreneurs, because of the many experiences they have. Likewise, the influence of parents' work on the growth of their children's entrepreneurial spirit is very significant.

2. Educational factors Good education will provide better knowledge in managing business. It will go a long way in overcoming the problem of correcting irregularities in business.

3. Age factor, age can have a correlation with the level of success if it is associated with the length of time someone has been an entrepreneur. In other words, the older an entrepreneur is the more experience he has in the field of business.

4. Factors of Work Experience Work experience is a driving factor for the success of an entrepreneur. Experience of dissatisfaction and failure has also become one of the motivations for developing new businesses.

Conceptually, an entrepreneur can be defined from several points of view and context as follows:

1. For economists, entrepreneur is a person who combines resources, labor, material and other equipment to increase a higher value than before, and is also a person who introduces changes, innovations, and other production improvements.

2. For psychologists, an entrepreneur is someone who has an internal power drive to achieve something, likes to conduct experiments or to show his freedom outside the power of others.

3. For a businessman or entrepreneur, it is a threat, a new competitor and it can also be a partner, supplier, consumer or someone who can be worked with.

4. An investor sees entrepreneurship as someone who creates welfare for others, who finds new ways to use resources, reduces waste, and opens jobs that are liked by the community.

Local wisdom is a view of life and knowledge as well as various life strategies in the form of activities carried out by local people in responding to various problems in fulfilling their needs. In foreign languages, it is often conceptualized as local wisdom or local knowledge "local knowledge" or local generous local intelligence Fajarini (2014: 123).Coffee is one of the mainstay commodities of the Gayo Highlands, covering the districts of Central Aceh, Bener Meriah and Gayo Lues. Not only has it with a distinctive taste and quality, Gayo Arabica Coffee is also the life support for people in three districts. The process

\footnotetext{
${ }^{6}$ Big Indonesian Dictionary, (Jakarta: Language Center, Ministry of National Education of Indonesia, 2014), p. 201.

${ }^{7}$ Sukiman, Learning Media Development, (Yogyakarta: PT. Pustaka Insan MAdani, 2013), p. 53.
} 
of cultivating coffee, from land clearing to post harvest, is inseparable from the role of women in the area, because they become coffee farmers, the existence of women is like a mother who cares for her child. This event was held by the Aceh Culture and Tourism Office, in a series of the 2018 Gayo Alas Mountain International Festival (GAMIFest) which began on November 19 and ended on November 21. Events like these have the opportunity to promote coffee. By empowering regional potentials such as coffee, it is expected to be able to improve the welfare of the community. Community welfare, a term often used in academic terminology as social welfare, has experienced a shift in its understanding and use. Social welfare refers to good living conditions, the fulfillment of material needs for life, spiritual needs (it is not enough to admit religion but the real manifestation of religion such as respecting others), social needs such as regular orders, manageable conflicts in life, security can be guaranteed, justice can be enforced where everyone has an equal position before the law, reducing socio-economic inequality. Midgley (2005: 21) conceptualizes the three categories of achievement regarding welfare, namely, first, the extent to which social problems can be regulated. Second, the extent to which needs can be met and third, the extent to which the opportunity to improve the standard of living can be obtained. All of these can be created in life together, both at the family, community and community levels at large.

\section{Research Methods}

The research in this writing is qualitative to determine how the strategy of developing entrepreneurship based on local wisdom at the Department of Trade, Cooperative Small and Medium Enterprises, Aceh Tengah District. Then this study also uses Analytic Network Process (ANP) in determining the development of entrepreneurship based on local wisdom. ANP is a qualitative method for a decision-making process with a general framework without making assumptions about the independence of elements at a higher level than the elements. Elements at a low level and about the independence of the elements in a level. By using ANP, we know in detail which things are the most priority or important of problems, strategies and solutions, because sometimes there are a lot of policies or policy making, there are many limitations related to resources so we need to know and understand which ones should be the key first / main problem or main strategy.

\section{Discussion}

The problem is constructed in a model in order to make it easier for researchers or respondents to understand the problem of entrepreneurship development strategies based on local wisdom. After decomposing the problem, a general framework for problem analysis is obtained which has 8 (eight) clusters, namely:

1. Aspects have three elements, namely, Disperindagkop, Entrepreneurs, and academics.

2. The problem of Disperindagkop has three elements, namely the public mindset, it is difficult to accept reforms and partnerships.

3. Entrepreneurial problems have three elements, namely capital, marketing, and raw materials.

4. Academic problems have three elements, namely entrepreneurship, innovation and creative education.

5. The solution for Disperindagkop has three elements, namely entrepreneurship education, comparative studies and cooperation. 
6. The entrepreneurial solution has three elements, namely entrepreneurial cooperation, creative competitions and farmer cooperation.

7. Academic solutions have three elements, namely character education, seminars / workshops and curriculum.

8. The strategy has four elements, namely collaboration with schools / campuses related to entrepreneurship education, comparative studies to other areas, collaborating with local banks related to capital or business training or between business units in developing new creativity and innovation and cultural festivals.

In terms of developing entrepreneurship, the government has tried to carry out various entrepreneurship developments in Central Aceh Regency by, for example, conducting Barista training, besides that the Office has made it easier for Central Aceh residents in assisting business permits for business people. Among others, the registration of trademarks, even the costs are also borne by the Industry and Trade Office, even for the halal certificate, the Ministry of Industry and Trade has collaborated with the province in issuing halal certificates. However, there are still some deficiencies in the effort to develop entrepreneurship because not all of the training activities related to entrepreneurship can be followed by the community due to the limited quota of participants and this activity requires large funds, but sometimes the budget provided must be shared with other activity posts. The government is very supportive of the development of entrepreneurship in Central Aceh Regency, one form of government support is by providing barista training. In addition, business people are also given convenience in processing permits. Disperindag must continue to promote entrepreneurial activities for the community, the community that is meant here is not only for business people but also for people who are just about to start their business and people who have not at all thought about doing business activities. Furthermore, the most problem with entrepreneurs is related to the availability of raw materials.

In addition to the above problems, character education is needed in the formation of an entrepreneurial spirit in a person. So far, entrepreneurial education has been available on campuses in Central Aceh Regency but it is only limited to certain study programs. In addition, entrepreneurship education should have been obtained since primary education, why? Because entrepreneurial character is needed from an early age so that the entrepreneurial spirit is inherent and fundamental to a person's personality. So that there should be a special curriculum for entrepreneurs both in schools and even up to the university level so that entrepreneurial character can be formed early on.

The main focus of the problem in the development of entrepreneurship at the Industry and Industry Office is the lack of cooperation / partnership in conducting business activities. This can be seen from the high individualistic attitude of the community, which, in part, have not been able to accept reforms and consider themselves to be right. This makes it difficult for the development of entrepreneurship, considering that realizing one business goal / objective requires solid cooperation. In addition, the most important problem in developing entrepreneurship is the mindset of the people who still expect after graduating from formal education to work in an office. Expectations are high after becoming a graduate to be able to get a decent job so that they can achieve the coveted welfare of life.

Marketing that is still not optimal, lack of raw materials and even lack of capital for entrepreneurs are problems that require solutions from related parties. There must be a synergy between business people and Disperindag and other agencies related to product marketing. This is because promotional activities also require the cooperation of various parties so that other people know that there are good products available in Central Aceh District. High levels of creativity and innovation are needed in shaping the spirit of 
entrepreneurship. In the process of getting it requires education which should be done early on. There should be a special education related to entrepreneurship in public schools and campuses. Seeing that in Central Aceh several private schools have implemented, for example, the "Maket Day" activity where the main objective of this activity is to form an entrepreneurial spirit in its students. It is better if there is a curriculum that really aims at forming an entrepreneurial spirit from an early age in a person. In addition to character education, seminars can also be held to motivate people to foster an entrepreneurial spirit. The following is a picture of a ranking based model framework:

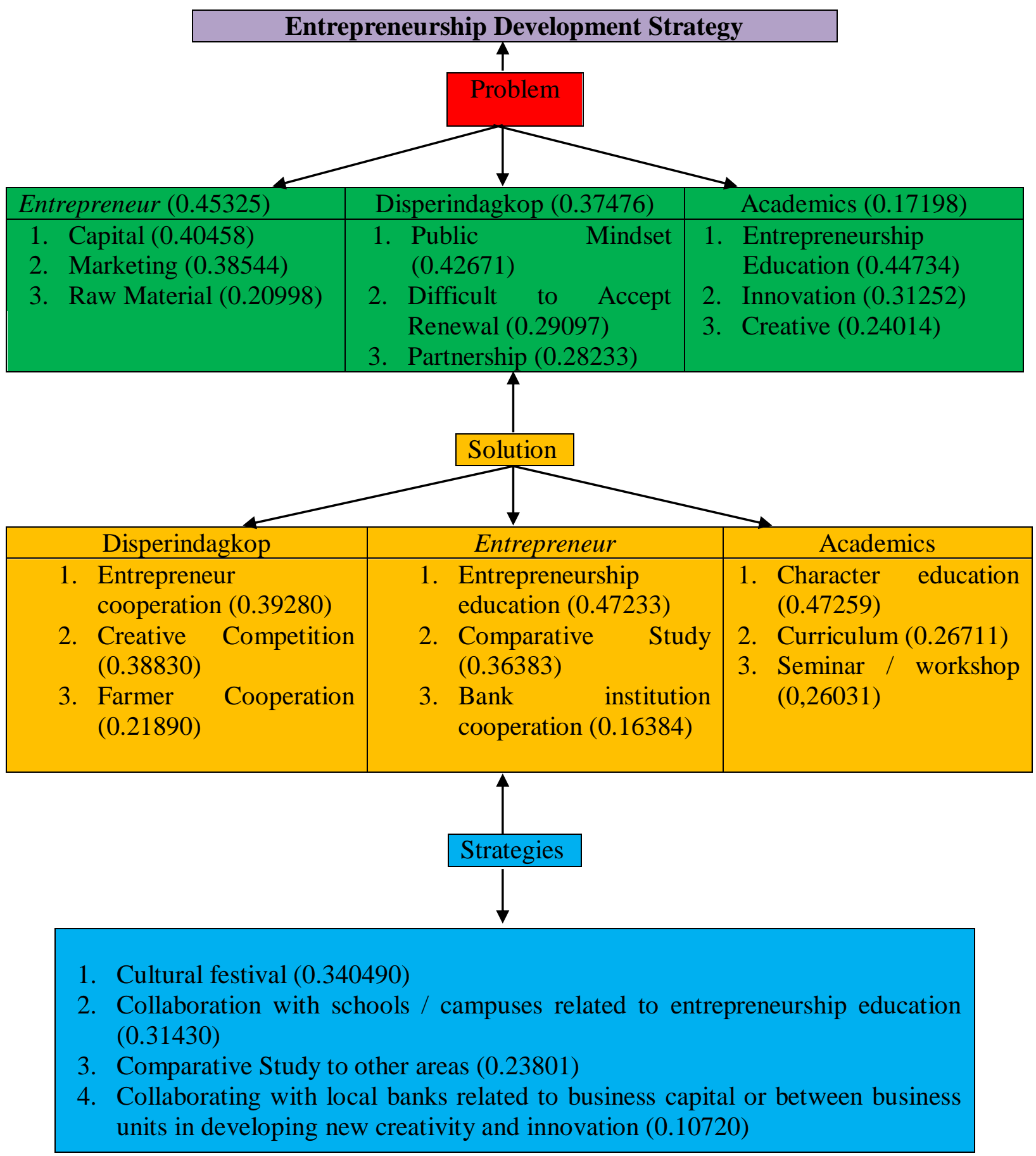

Figure 1. Model Framework Based on Ranking 


\section{Conclusion}

The most priority aspect in determining an entrepreneurship development strategy based on local wisdom is entrepreneurship / society, the people here, especially the people of Central Aceh, must have high innovation and creativity in increasing competitiveness. Competitiveness motivates people to develop their products to be more attractive so that they are attractive to market. The next strategy was followed by the Ministry of Industry and Trade, the Ministry of Industry and Trade here as part of the government should be relied on by the community. The government is present, of course, has the aim of improving people's lives. And who ranks last is the problem of academics, academics are expected to be able to create people who have an entrepreneurial spirit. Everyone who has an entrepreneurial spirit certainly has a high and strong will in facing various problems and is able to create jobs for other people and not the type of person who is looking for work. Synergy is needed.

\section{References}

Abdurrahman, Nana Herdiana. (2013). Manajemen Bisnis Syariah dan Kewirausahaan, Bandung: CV. Pustaka Setia.

Amanah, Dita. (2013). Pengantar Manajemen. Bandung: Citapustaka Media Perintis.

Amin, M and Priansah, P. (2019). Marketing Communication Strategy to Improve Tourism Potential. Budapest International Research and Critics Institute-Journal (BIRCI Journal). P. 160-166.

Ascarya \& Atika R Masrifah, Aplikasi Analitic Network Process dengan menggunkan Superdecision 2.2.6 (Jakarta:t.th,)

Ascarya dan Yumanita, Diana. (2010). "Determinan dan Persistensi Margin Perbankan Konvensional dan Syariah di Indonesia" working paper series No. WP/10/04. Pusat Pendidikan dan Studi Kebanksentralan Bank Indonesia

Ascarya. (2011). "The Persistence of Low and Profit and Loss Sharing Financing in Islamic

Banking. The Case of Indonesia", Review of Indonesian Economics and Business Studies, Vol 1. LIPI Economic Research Center.

Ascarya. (2007) akad dan bank Syariah. Jakarta: Grafindo Persada.

Ascarya. (2005). Analytic Network Process (ANP): Pendekatan Baru Studi Kualitatif, Seminar Intern Program Magister Akuntansi Fakultas Ekonomi di Universitas Trisakti, Jakarta.

Ascarya. (2005). Analitic Network Process (ANP): Pendekatan Baru Studi Kualitatif, Jakarta: Pusat Pendidikan dan Studi Kebanksentralan Bank Indonesia.

Asnawi. (2017). Nur dan Muhamad Asnan Fanani, Pemasaran Syariah, Teori, Filosofi dan Isu-Isu Kontemporer, Depok: PT. Raja Grafindo Persada.

B. Prihatin Dwi Riayanti. (2003). Enterpreneurship dari Sudut Pandang Psikologi Kepribadian, Jakarta: Grasindo.

Dianto, E. et al. (2020). BNI Marketing Strategy for Credit Cards in Dealing Global Competition in State Bank Indonesia (Persero) Tbk Banda Aceh Branch Office. Budapest International Research and Critics Institute-Journal (BIRCI-Journal). P. 1134-1146

Del I. Hawkins and David L. Mothersbaugh. (2010). Consumer Bihavior: Building Marketing Strategy, 11 th ed., Philippine: The McGraw-Hill Companies, Inc.

Departemen Pendidikan Nasional. (2012). Kamus Besar Bahasa Indonesia: Pusat Bahasa, Jakarta: Gramedia Pustaka Utama.

Dokumen Dinas Perdagangan Koperasi Usaha Kecil dan Menengah tentang Profil DPKUKM 
Hasan \&M.Iqbal. (2002). Pokok-pokok Materi Metodologi Penelitian dan Aplikasinta, Bogor: Ghalia Indonesia.

Herdiana Abdulrahman, Nana. (2015). Manajemen Bisnis Syariah dan Kewirausahaan, Bandung: Pustaka Setia.

Huda, Nurul et al. (2015). Ekonomi Pembangunan Islam, Jakarta: Prenadamedia Group.https://travel.kompas.com/read/2018/11/21/110059527/gamifest-masih-ada-kinidengan-konsep-perempuan-dan-kopi?page=all.

J. Winardi. (2004). Entrepreneur dan Entrepreneurship, (Jakarta: Prenada Media)

John W, Creswell. (2014). Research Design, Qualitative, Quantitative and Mixed Methods Approach, California: SAGE.

Kamil, Sukron. (2016). Ekonomi Islam, Kelembagaan. Dan Konteks Keindonesiaan, Dari Politik Makro Ekonomi Hingga Realissi Mikro, Jakarta: PT. Rajagrafindo Persada.

Machendrawaty, Nanih dan Agus Ahmad Safei. (2001) Pengembangan Masyarakat Islam, Bandung: PT Remaja Rosdakarya.

Pontas M. Pardede. (2011). Manajemen Strategik Dan Kebijakan Perusahaan, (Jakarta: Mitra Wacana Media.

Rachmat. (2014). Manajemen Strategik, Bandung: CV Pustaka Setia.

Rozan W Saalty. (2003). The Analitical hirarcy processfor Decision Making and The Analitical NetworkProcess (ANP) for Decesion meaking with dependence and feedback, University of Pittsburgh: Creative Decision Foundation.

Rusydiana, Aam Slamet. (2016). Analisis Masalah Pengembangan Perbankan Syariah di Indonesia: Aplikasi Metode Analitic Network Process, Esensi: Jurnal Bisnis dan Manajemen Volume 6 (2), Oktober.

Saaty et.all. (2006). Decision making with the Analitic Network Process Economics, Political, Social And Technological Application with Benefits, Opportunities, Cost and Risks. Springer. RWS Publication: Pittsburgh.

Sahroni, Oni dan Adiwarman A. Karim. (2015). Maqashid Bisnis dan Keuangan Islam: Sontesis Fiqih dan Ekonomi, Jakarta: PT. Rajagrafindo Persada.

Seurame. (2019). Melatih dan Memberi Akses Modal UMKM, Edisi 25 tahun.

Santoso, Teguh. (2011). Marketing Strategic Meningkatkan Pangsa Pasar Dan Daya Saing, (Jakarta: Oryza)

Shihab, M. Quraish. (2008). Berbisnis dengan Allah, Tangerang: Lentera Hati, Cetakan Ke. 2.

Sugiyono. (2012). Metode Penelitian Kuantitatif, Kualitatif dan R \& D, Bandung: Alfabeta.

Sugiyono. (2009). Metode Penelitian Bisnis (Pendekatan Kuantitatif, Kualitatif dan R \&D ), Bandung : Alfabeta.

Sukiman. (2013). Pengembangan Media Pembelajaran, Yogyakarta: PT. Pustaka Insan Madani.

Syauqi Beik Irfan dan Laily Dwi Asriyanti. (2016). Ekonomi Pembangunan Syariah, Jakarta: PT. Rajagrafindo Persada.

Tanjung, Hendri \& Abrista Devi. (2013). Metodologi Penelitian Ekonomi Islam, Jakarta: Gramata Publishing, cet. ke. 1.

Usman, Husaini dan Nurdin Eko Raharjo. (2012). Model Pendidikan Karakter Kewurausahaan di Sekolah Menengah Kejuruan, Jurnal Pendidikan Teknologi dan Kejuruan, Volume 21, Nomor 2, Oktober.

Yusuf Hamali, Ali dan Eka Sari Budihastuti. (2017). Pemahaman Kewirausahaan: strategi mengubah pola fikir "orang kantoran" menuju pola fikir "wirausahawan" sukses, Jakarta: Kencana.

Winardi. (2004). Entrepreneur dan Entrepreneurship, Jakarta: Prenada Media. 